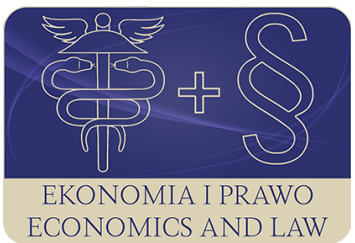

EKONOMIA I PRAWO. ECONOMICS AND LAW

Volume 20, Issue 3, September 2021

p-ISSN 1898-2255, e-ISSN 2392-1625

www.economicsandlaw.pl

EKONOMIA I PRAWO
ECONOMICS AND LAW

ORIGINAL ARTICLE

received 08.10.2020; revised 10.09.2021; accepted 30.09.2021

Citation: Wosiek, M. (2021). Unemployment as a determinant of local service-oriented entrepreneurship: a case study of Poland. Ekonomia i Prawo. Economics and Law, 20(3), 693-708. https://doi.org/10.12775/EiP.2021.041.

\title{
Unemployment as a determinant of local service-oriented entrepreneurship: a case study of Poland
}

\author{
MAEGORZATA WOSIEK \\ University of Rzeszow, Institute of Economics and Finance, ul. Ćwiklinskiej 2, 35-601 Rzeszow, \\ Poland \\ $\square$ mwosiek@ur.edu.pl \\ orcid.org/0000-0002-0503-001X
}

\begin{abstract}
Motivation: Unemployment is an important entrepreneurship determinant which is captured by the unemployment push/pull hypotheses. Those issues remain underexplored, with only few studies investigating the relationship between unemployment and the sector structure of entrepreneurship, while considering the specificity of the local economy.

Aim: The main goal of the study is to assess the impact of local unemployment rate on the number of newly registered service businesses in Poland, taking into account both the heterogeneity of that sector and the specificities of local economies in 2003-2018.

Results: The research results show that in Poland growing unemployment contributed to the increasing registration of new service businesses, which empirically supports the unemployment-push hypothesis. Both the occurrence and the intensity of the unemployment-push effect were conditioned by territorial factors, with the higher elasticity

of entrepreneurship in relation to unemployment changes in lagged local units.
\end{abstract}

Keywords: unemployment; entrepreneurship; local economy; Poland JEL: RI2; R30

\section{Introduction}

Due to its close relationship with socioeconomic development processes, entrepreneurship is a key research area in mainstream economics. A major role in that discourse is played by research focusing on the identification of mech- 
anisms that link entrepreneurship to the labour market. This covers not only the role of entrepreneurship in creating jobs (Stephens et al., 2013) but also the reverse impact that unemployment or wages have on the industry structure and dynamics of newly opened businesses. The way the labour market influences entrepreneurship shapes the longevity and innovativeness of enterprises (van Stel et al., 2021), and determines the either stabilising or destabilising influence of entrepreneurship on the economy (Fritsch et al., 2015). Identification of those mechanisms is also significant for the proper selection of instruments to stimulate development (through entrepreneurship) in peripheral regions (Urbano et al., 2020).

While most research findings suggest that growing unemployment fosters the creation of new businesses (Fritsch et al., 2015; Plehn-Dujowich, 2013), they also signal that the correlation is not universal. Its occurrence and intensity depends on the specificity of the industry (Konon et al., 2018), the scale of labour market problems (Congregao et al., 2012), institutional framework (Dilli et al., 2018; Urbano et al., 2020) and territorial specificity (Calá, 2018). For instance, in Europe the share of necessity entrepreneurship varies from 6-7\% in Nordic countries, ca. 20-25\% in Baltic states and Eastern European countries, till ca. 30-38\% in Mediterranean countries (van Stel et al., 2021). Those issues have attracted the interest of researchers relatively recently, with their analyses usually focused on highly developed countries. Meanwhile, these processes can unfold differently in the countries of Central and Eastern Europe, where the culture of entrepreneurial activities has a shorter background and requires continuous development (Remington \& Marques, 2020).

In order to fill this research gap, an attempt was made to assess the relationship between the labour market and entrepreneurship in Poland. Since a major aspect of the structural transformations of the Polish economy is the growing significance of the service sector for GDP, the study of the relationship between entrepreneurship and the labour market has been limited to service businesses. The main objective of this study is to assess the direction and strength of the impact of unemployment rate on the number of newly registered service businesses in Poland, taking into account both the heterogeneity of that sector and the specificities of local economies in 2003-2018. The following research hypotheses were verified:

- H1: In the 2003-2018 period, growing unemployment contributed to a subsequent increase in the number of newly registered service businesses.

- H2: The impact of unemployment on the number of newly registered service businesses was stronger in lagged local units in comparison to developed ones.

The paper is structured as follows. The first section is a critical overview of studies on the impact of unemployment on entrepreneurship. Section two contains a description of the methodology applied in the study. The following section discusses the diversity of entrepreneurship and its determinants at a local level in Poland and then verifies the impact of unemployment rate on the num- 
ber of newly registered service businesses. The paper concludes with the most important research findings.

\section{Literature review}

An important element of the links between unemployment and the formation of new businesses is captured by the unemployment-push hypothesis. According to this hypothesis, unemployment gives people a push to set up a business in response to lower employment opportunities or worse payment terms. The push hypothesis suggests the existence of a positive relationship between unemployment and entrepreneurship, that is, an opposite relation between the business cycle and the new business entry rate, and in consequence the stabilizing impact of entrepreneurship on the economy (businesses react counter-cyclically).

Viewed from this perspective, entrepreneurship is perceived as a form of escape from unemployment, which corresponds to necessity entrepreneurship (Block \& Wagner, 2010). Such entrepreneurship, however, is often transitory as the resulting businesses are usually less competitive (Beynon et al., 2019; Fairlie \& Fossen, 2018).

The unemployment-push effect does not arise by default but depends on:

- the specificity of the business activity (e.g. the capital and knowledge requirements): a positive effect of the unemployment rate on the start-up rate is expected, especially in small-scale easy-to-enter industries (Roman et al., 2013);

- the intensity of economic tensions: the push effect is disproportionally stronger when economic circumstances are worse (Congregao et al., 2012).

Consequently, it can be concluded that the unemployment-push effect is also conditioned by specific territorial factors. Higher vulnerability of entrepreneurship to unemployment fluctuations might be expected in local units with relatively high intensity of problems in the labour market (e.g. high unemployment) and a relatively high share of operational service activities. Nikolaev et al. (2018), based on a sample of 73 countries, indicate that the lower level of economic development (measured by GDP per capita) can also play a crucial role in explaining necessity-driven entrepreneurship. Moreover, they reveal an explanatory potential of income inequality in analysing cross countries differences in entrepreneurship. A higher level of income inequality hampers opportunity-motivated entrepreneurship and is conducive to engagement in entrepreneurship out of necessity.

It is also possible that the limited number of business opportunities during market downturn hampers entrepreneurship. Conversely, when the economic situation is good, the emerging market opportunities encourage people to set up businesses. This is referred to as the prosperity-pull hypothesis (Rampini, 2004). There is also a possibility that high unemployment rate (especially structural unemployment) may curtail market entry for businesses because the unemployed usually have fewer entrepreneurial skills and less capital available 
than employed individuals (van Stel \& Storey, 2004). These theories suggest a negative relationship between unemployment and new business formation.

Thus, the distinctive characteristics of lagged economies, in particular their structural problems, may mitigate the positive effect of unemployment rate on business entry rate. This may hamper, in particular, the emergence of new knowledge-based industries, since in lagged regions the demand for such goods and services is smaller, less stable and less diverse (Kantis et al., 2005). Moreover, peripheral areas usually lack access to information, business networks and financial resources critical to creating the conditions for external economies in knowledge-based sectors. A direct implication of this "structural territorial heterogeneity" is that firm entry determinants may differ across local units, especially between central and lagged provinces (Calá, 2018).

The issue remains underexplored, with only few studies focusing on the assessment of the relationship between unemployment and the sector structure of entrepreneurship, while taking into account the specificity of the local economy. The purpose of this study is to help fill this gap, in particular in relation to countries in Central and Eastern Europe.

\section{Methods}

The service sector comprises many diverse activities, which differ in terms of qualifications and capital requirements or geographic concentration and dynamics. In order to capture the effect of unemployment rate on entrepreneurship in the service sector, service activities (NACE Rev. 2) were clustered using the knowledge-intensity criterion (the share of employees with tertiary education). This dimension emphasises the qualifications necessary for the provision of services, and is crucial in service typology (Glückler \& Hammer, 2011).

In the case of Poland, the large numbers of less skilled employees is a typical feature of operational (OP) services, including trade, transportation, and accommodation and food service activities - sections $\mathrm{G}, \mathrm{H}$, I according to NACE Rev. 2 (Cyrek, 2012, pp. 186-187). The rest of the service sections form a group of knowledge-based (KB) services, which comprise two diverse service groups: business-oriented services (financial and insurance, real estate, professional and technical, administrative and support service activities - sections K, L, M, $\mathrm{N}$ ) and social services (education, human health and social work activities sections $\mathrm{P}, \mathrm{Q})$.

The specificity of service activities results in a special link between the service sector and the local environment (Carree, 2002). Thus, the investigation of the relationship between unemployment and entrepreneurship has been performed at the local level (poviats; 379 local units). Local units (LUs) were divided into two groups, based on the local labour market conditions:

- less developed LUs (259): featuring unemployment rate that was permanently higher than the national average in 2003-2018 (average unemployment rate in those LUs was $17.4 \%$ compared to the national average $14.7 \%$ ); 
- developed LUs (120): featuring permanently below-average unemployment rate in 2003-2018 (8.7\%).

In order to verify the links between unemployment rate and entrepreneurship, the following regression equation was employed (1):

$$
\ln Y_{i, j, t}=\alpha_{0}+\alpha_{i} \ln X_{i, j, t-1}+\beta_{i} Z_{j, t-1}+\left(\alpha_{j}+\mu_{t}+\varepsilon_{j, t}\right),
$$

where:

$Y_{i, j, t}$ - gross entry rate in specific service section $i$ in LU $j$ in year $t$;

$X_{i, j, t-1}$ - registered unemployment rate in LU $j$ in year $t-1$;

$Z_{j, t-1}$ - set of control variables in LU $j$ in year $t-1$;

$\alpha_{0}, \alpha_{i}, \beta_{i}$ - regression coefficients;

$\alpha_{j}$ - fixed-local effects,

$\mu_{\mathrm{t}}$ - fixed time effects;

$\varepsilon_{j, t}$ - error term of the specification.

Following Fritsch et al. (2015) and Konon et al. (2018), the gross entry rate into entrepreneurship (the number of new service businesses entered into the REGON registry per 1,000 inhabitants) was adopted as a proxy of entrepreneurship, as this indicator is considered to be better suited for identifying the relationship between the labour market and entrepreneurship. Additionally, $X_{i}$ and $Y_{i}$ variables were transformed into a natural logarithm in order to improve their distribution (in terms of normal distribution). Moreover, it allowed the interpretation of the obtained regression coefficient as the coefficient of elasticity. In order to control for local factors, which may influence entrepreneurial entry, based on the literature review, the set of control variables $Z_{j}$ was included into the regression equation (Table 1). It reveals that entrepreneurship is not only determined by the current economic situation (unemployment), but also by the specificity of local economies.

The fixed effects panel ${ }^{1}$ approach was applied, as it accounts for unobserved locally specific conditions for business activity, which also limits the omitted variable bias. Driscoll-Kraay fixed effects estimators were chosen as an estimation method, as they are robust with regard to very general forms of cross-sectional, spatial and temporal dependence (Hoechle, 2007). A fixed effects estimator, however, is unable to take fully into account endogeneity, which results from the two-way relationship between unemployment and entrepreneurship. In order to avoid possible endogeneity problems, in the regression equation, the explanatory variables were included with a time lag of one period (Konon et al., 2018). As a robustness check, equation (1) was re-estimated using the GMM estimator, which offers a different solution to the endogeneity problem.

The present study has some limitations, as it focuses on the short-term oneway effects of unemployment on start-up activity in the service sector. Due to relatively short time-series data it was difficult to investigate the two-way relationship between unemployment and entrepreneurship, as a longer time

${ }^{1}$ The results of the Hausman test $(\mathrm{p}<0.001)$ confirm the validity of this estimation method. 
frame is required in order to detect the feedback effect that newly registered businesses have on the labour market (Fritsch et al., 2015). The applied research methods, however, can reflect the general impact of unemployment on entrepreneurship. Thus, the obtained research results allow the verification of the research hypotheses.

\section{Results}

Approximately 331,300 businesses were registered in Poland every year during the 2003-2018 period, $75 \%$ of which $(249,100)$ were in the service sector. The average annual gross entry rate in the service sector was 5.43 (2.77 for OP services and 2.03 for $\mathrm{KB}$ services). The sector of commerce (retail, wholesale and repair) had the highest number of entries, with around 85,100 per year (2.22). The processes varied across time and space (Chart 1). For the entire analysed period, local units in a better labour market situation had higher new business registration rate in the service sector ( 6.27 on average) compared to lagged units (5.04).

Despite those differences, the new business registration processes in the service sector were quite similar for both local unit types. An upward trend could be observed for the rate of new service business registrations until 2010. In subsequent years (2011-2017), the number of newly registered businesses decreased. The next gradual increase in the gross entry rate in services was not observed until 2017. Changes taking place in OP services were similar, while KB services were characterised by an upward trend throughout the 2003-2018 period, with only a short-term drop in 2011. Moreover, after 2009, the gross entry rate in $\mathrm{KB}$ services in developed LUs increased more dynamically than in lagged ones. As a result, local disproportions in Poland regarding the number of registered businesses in KB services increased after 2009.

Labour market conditions also varied considerably across localities. Nevertheless, in 2003-2018, the changes in unemployment rate had a similar direction in both lagged and developed LUs. In all LUs, three sub-periods could be distinguished: 2003-2008 (decrease in unemployment rates), 2008-2013 (increase), 2013-2018 (downward tendency). The resulting unemployment levels, however, were higher in lagged LUs compared to developed ones due to the general condition of the local labour markets.

These differences were of mostly structural nature (Chart 2). Developed LUs offered conditions that were more conducive to entrepreneurship, which is reflected in: a higher urbanisation rate $\left(Z_{2}\right)$, a higher share of services in the structure of the working population $\left(Z_{3}\right)$, a favourable businesses environment $\left(Z_{4}\right)$ and a better transport infrastructure $\left(Z_{5}\right)$. Only the slightly higher percentage of inhabitants in post-working age $\left(Z_{1}\right)$ and the higher alternative costs of business $\left(Z_{6}\right)$ could limit the number of newly created businesses in more developed LUs. 
In all local units, changes to unemployment rates positively correlated with the number of newly registered businesses. The values of the Pearson correlation coefficients were similar for lagged and more developed LUs and they were as follows (LD/D): all services: 0.124/0.120; OP services: 0.163/0.178; KB services: $0.048 / 0.061(\mathrm{p}<0.05)$. This would suggest the existence of the push effect in the service sector in all types of LUs and a stronger impact of unemployment on entrepreneurship for OP services.

Estimation (1) results confirm that unemployment rate in Poland contributed, ceteris paribus, to the growing registration of new service businesses in the subsequent period (Table 2). The push effect was observed for both OP services (Estimation 2) and KB services (Estimation 3). The results are statistically significant and the Driscoll-Kraay and GMM estimations appear to be consistent, as indicated by the post-hoc tests.

The results are consistent with the research findings to date, which note that lower barriers to entry make the service sector particularly prone to the growing registration of businesses in periods with higher unemployment (Roman et al., 2013). What may seem surprising, however, in light of theoretical assumptions is that $\mathrm{KB}$ services were more elastic in response to unemployment rate fluctuations than OP services. The heterogeneity of $\mathrm{KB}$ services was also revealed. While unemployment had a statistically significant impact on the number of newly registered businesses in the sector of business-oriented services (Estimation 4), the impact was statistically insignificant (Estimation 5) for social services (Table 2).

The lower sensitivity of educational and medical services to unemployment rate changes may be linked to the fact that they are public goods that satisfy the basic needs of society. In the case of business-oriented services, while the study by Plehn-Dujowich (2013) also signals that business-oriented services are subject to the push effect, the study by Konon et al. (2018) demonstrates that the entry rate for financial services in the German economy has no statistically significant relationship with the unemployment rate. In Poland, the positive elasticity of the gross entry rate in reaction to changes in the unemployment rate in KB services can be explained, not by attempts to avoid unemployment, but rather by the drive of highly skilled specialists to achieve a satisfactory financial situation and increase their ability to achieve professional goals. An example of this are IT services, where a very dynamic rise of B2B business arrangements can be observed as a flexible form of employment and, simultaneously, as a way to reduce operational costs (Money.pl, 2019).

However, regarding accounting advisory services an explanation could be linked to active labour market policy, in particular to instruments encouraging the creation of new enterprises. In Eastern Poland the most popular businesses established by unemployed individuals granted self-employment grants were service businesses (72\%) such as: renovation and construction, cosmetic, gastronomic, and accounting advisory services (Supreme Audit Office, 2015). 
The estimations (6-15) also show that the strength of the impact of unemployment on the number of newly registered businesses differed between developed and lagged LUs. In lagged LUs, the push effect was present in all service groups, except for social services (Estimation 11-15). In developed LUs, the statistically significant positive impact of unemployment rate on the number of newly registered businesses was recorded only for KB services and business-oriented services (Estimation 8-9). Moreover, the elasticity of the gross entry rate in $\mathrm{KB}$ services against the unemployment rate was over twice as low as for less developed LUs (Table 2).

As regard financial services, in Slovakia, for instance, it is observed that the chains of financial intermediaries operating on a multi-level marketing basis seem more successful in recruiting agents in lagged areas. Unfortunately, there is no data available on the development of the chains of financial agents in Poland with respect to the territorial aspect. Thus, it is difficult to say whether a similar pattern as in Slovakia exists in Poland.

The research results show that both the occurrence and the intensity of the unemployment-push effect are conditioned by territorial factors connected with the general condition of the local labour market. Entrepreneurship forced by unemployment is primarily a characteristic of lagged LUs. This is visible in the service sector, which is especially prone to the occurrence of the unemployment-push effect. This shows that the territorial aspect is important in shaping the mutual relationships between entrepreneurship and the labour market. The situation observed in Poland is not unique. Studies by Beynon et al. (2019) and Huggins et al. (2017) show that lagged regions display a greater tendency to create new businesses as a way of improving the situation in the labour market. Nonetheless, such entities are more likely to go out of business, which may undermine their impact on other dimensions of socioeconomic development.

The differences between lagged and developed LUs are also visible in the impact of the control variables on the elasticity of entrepreneurship in relation to unemployment changes (Table 2). For developed LUs, those were primarily the higher share of the service sector $\left(Z_{3}\right)$ and the general entrepreneurial climate $\left(Z_{4}\right)$ encouraging entry in the service business. To the contrary, for lagged LUs, the process was highly connected with the quality of transport infrastructure $\left(Z_{5}\right)$ and demographic structure of a population $\left(Z_{1}\right)$.

Remarkably, the links between the local entrepreneurial climate and entrepreneurship in developed LUs seem to be relevant only in KB and, business-oriented services. This implies that a favourable economic environment especially enhances firm creation in modern service sectors, thus contributing to the promotion of local structural changes driven by firm entries in KB services. 


\section{Conclusion}

The study has led to the following conclusions:

1. Entrepreneurship in service sector in Poland in the 2003-2018 period was co-shaped by unemployment rate fluctuations. Unemployment growth contributed to the increasing registration of service businesses, which empirically supports the unemployment-push hypothesis. The phenomenon was present in both operational services and knowledge-based services (except for social services). In this context, the first research hypothesis can be considered as positively verified.

2. The impact of unemployment on entrepreneurship in the service sector depended on the intensity of the problems in the local labour market. In less developed local units, growing unemployment stimulated the registration of businesses across all service groups (other than social services). In developed local units, a similar impact was recorded for business-oriented services only and, moreover, the elasticity of entrepreneurship in relation to unemployment was almost twice as low as that of lagged local units. Under these circumstances, hypothesis number 2 can be deemed positively verified.

3. The findings show that, in lagged local units due to a less favourable businesses environment, it may be particularly difficult to promote the local structural changes driven by new firm entries in knowledge-based services. Moreover, the occurrence of the unemployment-push effect suggests the ubiquitous presence of necessity entrepreneurship within service sections in these local units, which additionally hinders the process of their structural modernization. The results point to the special supporting role of institutions, which should contribute to the arrangement of local business organisations, and to the provision of expert services for local businesses in lagged local units to a hitherto greater extent. These conditions are crucial for the fostering opportunity recognition, and in consequence longevity of new businesses and for the strengthening of their impact on socioeconomic development processes.

The study focuses on the short-term, one-way relationship between unemployment and entrepreneurship, while the level of sectoral aggregation is still relatively high. The possible effects of adjacent provinces are also not taken into account. The results, however, are quite clear-cut across both the service sector and local units. Further research should, thus, focus on more detailed analyses of individual service sections. The availability of longer time-series may provide further insights into the two-way relationship between unemployment, localand service-specific factors and entrepreneurship. 


\section{References}

Armington, C., \& Acs, Z.J. (2002). The determinants of regional variation in new firm formation. Regional Studies, 36(1), 33-45. https://doi. org/10.1080/00343400120099843.

Bennett, D.L. (2019). Infrastructure investments and entrepreneurial dynamism in the U.S. Journal of Business Venturing, 34(5), 105907. https://doi. org/10.1016/j.jbusvent.2018.10.005.

Beynon, M.J., Jones, P., \& Pickernell, D. (2019). The role of entrepreneurship, innovation, and urbanity-diversity on growth, unemployment, and income: US state-level evidence and an fsQCA elucidation. Journal of Business Research, 101, 675-687. https://doi.org/10.1016/j.jbusres.2019.01.074.

Block, J.H., \& Wagner, M. (2010). Necessity and opportunity entrepreneurs in Germany: characteristics and earnings differentials. Schmalenbach Business Review, 62(2), 154-174. https://doi.org/10.1007/BF03396803.

Calá, D.C. (2018). Sectoral and regional determinants of firm dynamics in developing countries: evidence for low-, medium-and high-tech manufacturing in Argentina. CEPAL Review, 124, 121-142. https://doi. org/10.18356/0451c758-en.

Carree, M. (2002). Does unemployment affect the number of establishments: a regional analysis for US States. Regional Studies, 36(4), 389-398. https:// doi.org/10.1080/00343400220131151.

Congregao, E., Golpe, A.A., \& van Stel, A. (2012). The 'recession-push' hypothesis reconsidered. International Entrepreneurship and Management Journal, 8(3), 325-342. https://doi.org/10.1007/s11365-011-0176-1.

CSO. (2021). Local data bank. Retrieved 20.05.2020 from https://bdl.stat.gov. $\mathrm{pl} / \mathrm{BDLS} / \mathrm{start}$.

Cyrek, M. (2012). Rozwój sektora ustug a gospodarka oparta na wiedzy. Uniwersytet Rzeszowski.

Dilli, S., Elert, N., \& Jovanovic, B. (2018). Varieties of entrepreneurship: exploring the institutional foundations of different entrepreneurship types through "varieties of capitalism" arguments. Small Business Economics, 51(2), 293-320. https://doi.org/10.1007/s11187-018-0002-z.

Fairlie, R.W., \& Fossen, F.M. (2018). Defining opportunity versus necessity entrepreneurship: two components of business creation. IZA Discussion Paper Series, 11258, 1-49. https://doi.org/10.2139/ssrn.3140340.

Fritsch, M., \& Falck, O. (2007). New business formation by industry over space and time: a multidimensional analysis. Regional Studies, 41(2), 157172. https://doi.org/10.1080/00343400600928301.

Fritsch, M., Kritikos, A., \& Pijnenburg, K. (2015). Business cycles, unemployment and entrepreneurial entry: evidence from Germany. International Entrepreneurship and Management Journal, 11(2), 267-286. https://doi. org/10.1007/s11365-014-0326-3. 
Glückler, J., \& Hammer, I. (2011). Pragmatic service typology: capturing the distinctive dynamics of services in time and space. The Service Industries Journal, 31(6), 941-957. https://doi.org/10.1080/02642060903078743.

Hoechle, D. (2007). Robust standard errors for panel regressions with cross-sectional dependence. The Stata Journal, 7(3), 281-312. https://doi. org/10.1177/1536867X0700700301.

Huggins, R., Prokop, D., \& Thompson, P. (2017). Entrepreneurship and the determinants of firm survival within regions: human capital, growth motivation and locational conditions. Entrepreneurship and Regional Development, 29(3-4), 357-389. https://doi.org/10.1080/08985626.2016.1271830.

Kantis, H., Angelelli, P., \& Moori Koening, V. (Eds.). (2005). Developing entrepreneurship: experience in Latin America and worldwide. Inter-American Development Bank.

Konon, A., Fritsch, M., \& Kritikos, A.S. (2018). Business cycles and start-ups across industries: an empirical analysis of German regions. Journal of Business Venturing, 33(6), 742-761.https://doi.org/10.1016/j.jbusvent.2018.04.006.

Mickiewicz, T. (2016). Tocqueville in Poland: social self-organization, business support policies of local authorities and entrepreneurship. WSIZ Working Paper Series, 19, 1-30.

Money.pl. (2019). Praca dla programistów: branża IT coraz chętniej przechodzi na samozatrudnienie. Retrieved 20.05.2020 from https://www.money.pl/ gospodarka/praca-dla-programistow-branza-it-coraz-chetniej-przechodzi-na-samozatrudnienie-6356830056912513a.html.

Nikolaev, B.N., Boudreaux, Ch.J., \& Palich, L. (2018). Cross-country determinants of early-stage necessity and opportunity-motivated entrepreneurship: accounting for model uncertainty. Journal of Small Business Management, 56(S1), 243-280. https://doi.org/10.1111/jsbm.12400.

Plehn-Dujowich, J.M. (2012). The dynamic relationship between entrepreneurship, unemployment, and growth: evidence from U.S. Industries. Retrieved 20.07.2020 from https://www.sba.gov/sites/default/files/advocacy/rs394tot.pdf.

Rampini, A. (2004). Entrepreneurial activity, risk, and the business cycle. Journal of Monetary Economics, 51(3), 555-573. https://doi.org/10.1016/j. jmoneco.2003.06.003.

Remington, T.F., \& Marques II, I. (2020). Partnerships for skill development in Russia. Post-Communist Economies, 32(1), 1-23. https://doi.org/10.1080/ 14631377.2019.1640990.

Rocha, H.O., \& Sternberg, R. (2005). Entrepreneurship: the role of clusters theoretical perspectives and empirical evidence from Germany. Small Business Economics, 24(3), 267-292. https://doi.org/10.1007/s11187-005-1993-9.

Roman, C., Congregado, E., \& Millán, J.M. (2013). Start-up incentives: entrepreneurship policy or active labour market programme. Journal of Business Venturing, 28(1), 151-175. https://doi.org/10.1016/j.jbusvent.2012.01.004. 
Stephens, H.M., Partridge, M.D., \& Faggian, A. (2013). Innovation, entrepreneurship and economic growth in lagging regions. Journal of Regional Science, 53(5), 778-812. https://doi.org/10.1111/jors.12019.

Supreme Audit Office. (2015). Dotacje z funduszu pracy na podjęcie dziatalności gospodarczej w Polsce Wschodniej. Retrieved 20.07.2020 from https://bip.nik.gov.pl/kontrole/wyniki-kontroli-nik/pobierz,llu p_14_093_201409150934111410773651 01,typ,kk.pdf.

Urbano, D., Audretsch, D., Aparicio, S., \& Noguera, M. (2020). Does entrepreneurial activity matter for economic growth in developing countries: the role of the institutional environment. International Entrepreneurship and Management Journal, 16(3), 1065-1099. https://doi.org/10.1007/ s11365-019-00621-5.

van Stel, A.J., \& Storey, D.J. (2004). The link between firm births and job creation: is there a upas tree effect. Regional Studies, 38(8), 893-909. https:// doi.org/10.1080/0034340042000280929.

van Stel, A.J., Barrientos-Marín, J., Caçador-Rodrigues, L., Millán, A., \& Millán, J.M. (2021). Measuring performance differentials across entrepreneurship types. International Entrepreneurship and Management Journal. Advance online publication. https://doi.org/10.1007/s11365-021-00755-5.

\section{Acknowledgements}

Author contributions: author has given an approval to the final version of the article.

Funding: this research was fully funded by the University of Rzeszow.

Note: the results of this study were presented at 9th Scientific Conference: Contemporary Economic Problems 'Thirty years of transformation' (September, 16, 2020, online, Poland). 


\section{Appendix}

Table 1 .

Set of control variables $\mathrm{Z}_{\mathrm{j}}$

\begin{tabular}{|c|c|c|}
\hline Variable* $^{*}$ & Description & Explanation \\
\hline$Z_{1}$ & percentage of persons at post-working age & $\begin{array}{l}\text { This variable is expected to hamper business } \\
\text { entries (Mickiewicz, 2016). }\end{array}$ \\
\hline$Z_{2}$ & $\begin{array}{l}\text { urbanisation rate (percentage of population living } \\
\text { in urban areas) }\end{array}$ & $\begin{array}{l}\text { More entries occur in concentrated areas because } \\
\text { firms benefit from local external economies } \\
\text { (Armington \& Acs, 2002). }\end{array}$ \\
\hline$Z_{3}$ & $\begin{array}{l}\text { share of services in the employment structure } \\
\text { of the local economy }\end{array}$ & $\begin{array}{l}\text { The share of the service sector is expected to fos- } \\
\text { ter entry rate (Fritsch \& Falck, 2007). }\end{array}$ \\
\hline$Z_{4}$ & total number of registered businesses per capita & $\begin{array}{l}\text { Industrial tradition may boost current entre- } \\
\text { preneurial activities, since it is likely that past } \\
\text { incumbents developed a favourable business } \\
\text { environment (Rocha \& Sternberg, 2005). }\end{array}$ \\
\hline$Z_{5}$ & $\begin{array}{l}\text { communal public roads surfaced per } 1,000 \mathrm{~km}^{2} \\
\text { (in } \mathrm{km} \text { ) }\end{array}$ & $\begin{array}{l}\text { Infrastructure development is expected to have } \\
\text { a positive impact on entries (Bennett, 2019). }\end{array}$ \\
\hline$Z_{6}$ & $\begin{array}{l}\text { average monthly gross wages (in relation } \\
\text { to the national average) }\end{array}$ & $\begin{array}{l}\text { The higher opportunity cost of self-employment } \\
\text { is expected to have a negative impact on entries. }\end{array}$ \\
\hline
\end{tabular}

Notes:

* As the Breitung panel unit root tests reveal that the levels of control variables $Z_{1}, Z_{2}, Z_{4}$ are not stationary, they are included in the regression equation as growth rates. The rest of the control variables were included in the logarithmic form.

Source: Own preparation. 


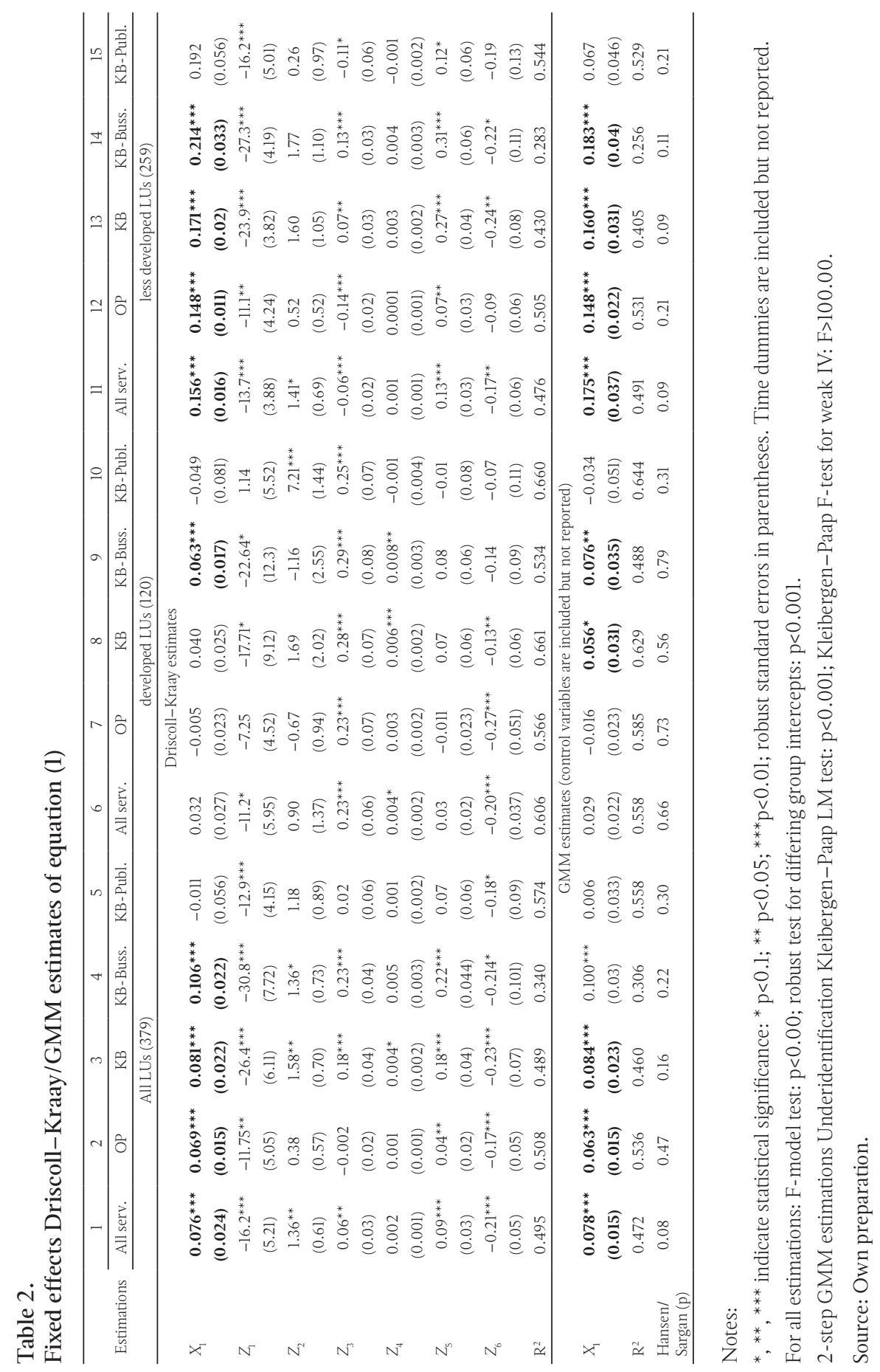




\section{Chart 1.}

Unemployment and business entry rates in the service sector at the local level, 2003$2018(\%)$

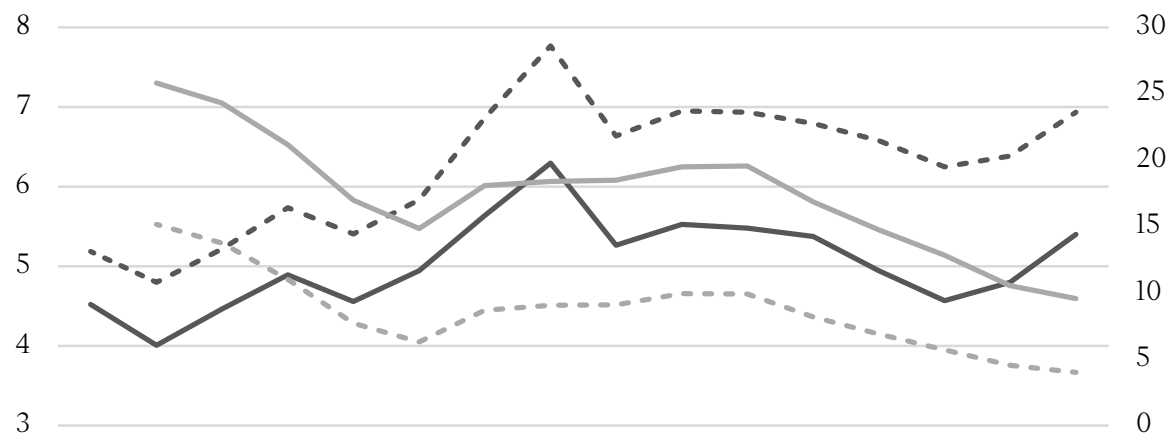

2003200420052006200720082009201020112012201320142015201620172018

_all services (LD) (left scale) _ _- - all services (D) (left scale)

_unemployment (LD) (right scale) _ - - - unemployment (D) (right scale)

4

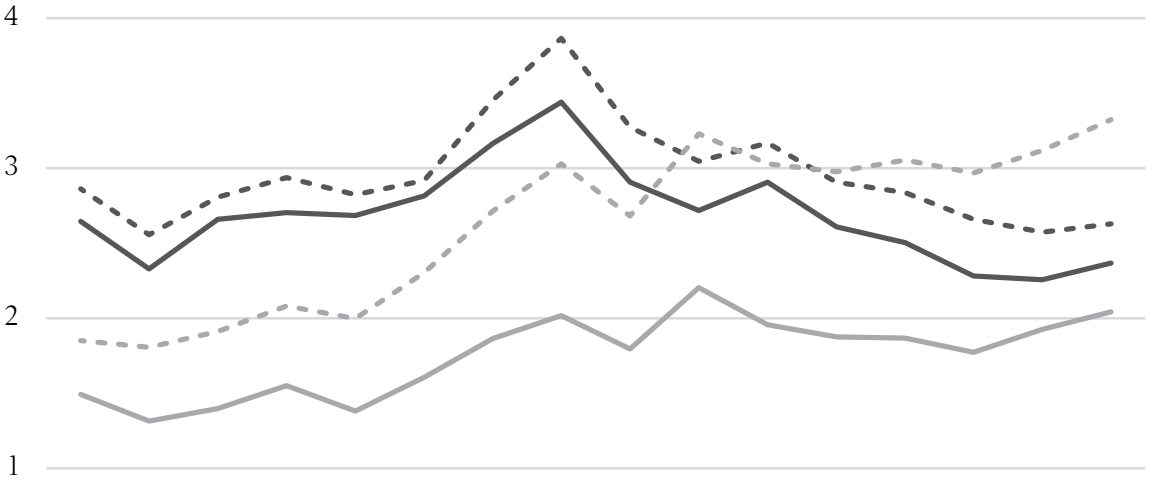

$200320042005200620072008200920102011201220132014 \quad 2015201620172018$

$\longrightarrow \mathrm{OP}(\mathrm{LD})$

-...OP $(\mathrm{D})$

$\mathrm{KB}(\mathrm{LD})$

$\cdots \mathrm{KB}(\mathrm{D})$

Notes:

D — developed local units, LD-Less developed local units; OP — operational services, KB — knowledge based services

Source: Own preparation based on CSO (2021). 
Chart 2.

Local diversity in determinants of entrepreneurship (2003-2018 average)

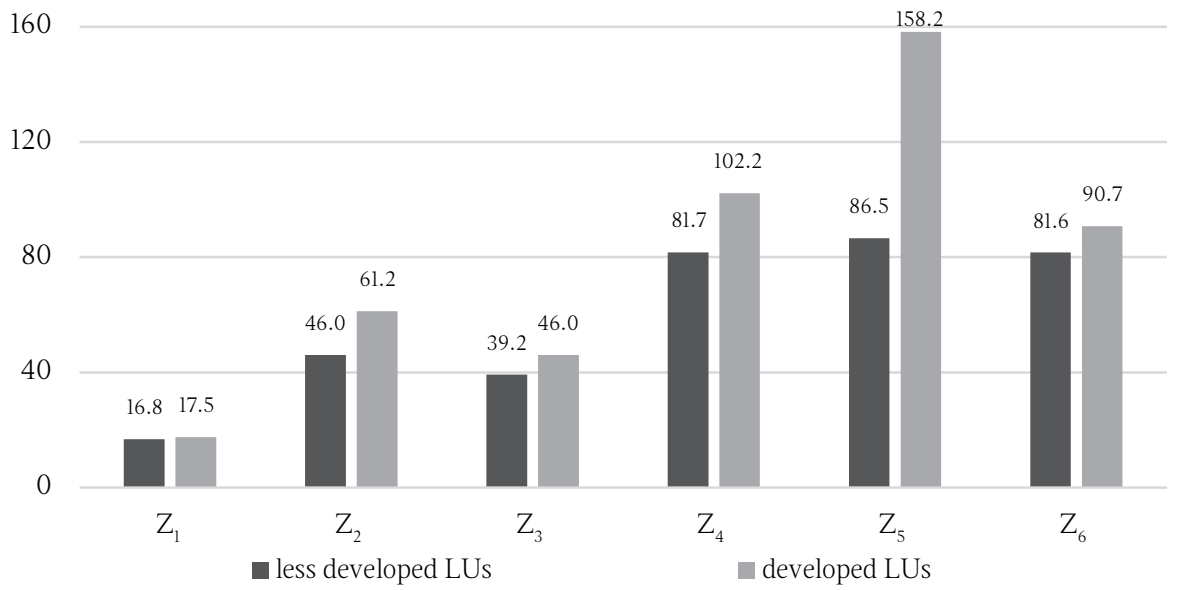

Source: Own preparation based on CSO (2021). 